\title{
Reading Plato: Between Tragedy and Comedy in Cratylus ${ }^{1}$
}

Leyendo a Platón: entre comedia y tragedia en el Cratylus

\author{
Juan Manuel López ${ }^{2}$ \\ Universidad Tecnológica de Pereira
}

Recibido: 12.09 .2021

Aceptado: 30.10 .2021

\begin{abstract}
This article is a discussion on the Platonic concept of dialogue as comedy. Plato's Cratylus: The Comedy of Language (Ewegen, 2014) was used as the central source for this article, which can provide the basis for positions on this issue in Latin America such as those exposed by Professor Buarque (2011) in our region and more generally by Gregorio Lury et al. (2018) in Ibero-America. In addition to the aforementioned work, a comparison with Plato's writing was made using a hermeneutic methodology based on Plato's writings and his multiples references to laughter throughout his work, in addition to Gadamer's clear interpretations of the work as a whole. This manuscript aims to accurately establish the existence of a Platonic commitment that is much closer to tragedy than comedy as a genre of interpretation. Thus, although there are sections entirely devoted to laughter in which Plato's humor can be appreciated, it cannot be the key to interpreting Plato's work, at least from the perspective of
\end{abstract}

\footnotetext{
${ }^{1}$ This text is a brief sample of the research work titled Cratylus: a study on Plato's language (ERC Code 1-133), in which my PhD thesis is framed. My thesis was almost entirely supervised by the renowned Professor Jairo Iván Escobar Moncada and, in view of his grievous passing away, was finally supervised by PhD Einar Monrroy. The information on this project can be verified at https://www.utp.edu.co/vicerrectoria/investigaciones/investigaciones/DetallesProyecto/2300 (date of access: June 19, 2020). 2jlmr@utp.edu.co https://orcid.org/0000-0003-1196-4174
} 
Ewegen's approach, which must be understood as an educational project, that is, a social transformation project.

Keywords: Tragedy, comedy, education.

\section{Resumen}

Este artículo es una discusión con el concepto platónico de diálogo entendido como comedia, Plato's Cratylus: The Comedy of Language (Ewegen, 2014. No hay traducción al español) fue usado como el recurso central de este artículo, el cual provee la base para diferentes interpretaciones en América Latina como las que defiende la profesora Buarque (2011) en nuestra región y, de manera mucho más general Gregorio Lury et al. (2018) en Ibero America. Sumado a ello, a diferencia del trabajo mencionado, este trabajo lleva a cabo una comparación con la obra de Platón usando una metodología de carácter hermenéutico basado en los escritos de Platón y sus múltiples referencias a la risa a través de su reflexión escrita; se toma como punto de referencia la consigna hermenéutica de tomar la clara interpretación como un todo. El presente trabajo tiende entonces, a diferencia de la propuesta de Ewegen, a establecer el esfuerzo platónico mucho más próximo a a la tragedia que a la comedia como género de interpretación. Aunque existan secciones referidas enteramente a asuntos graciosos en los cuales el humor se aprecia, esta no puede ser la clave para la interpretación platónica como lo sostiene el enfoque de Ewegen. La forma del diálogo platónico debe ser entendida en un proyecto educativo, es decir de transformación.

Palabras clave: Tragedia, comedia, educación. 
The older ones are indeed clearer in the sense that they acknowledge a clear terminus, while the new system it is supposed to look as if everything had a foundation

Ludwig Wittgestein

The following pages are proposed as an exercise to guide us through Plato's style of writing. In this article, we will support the idea that the style in the Dialogues of Plato, should it be taken as one of them (which turns to be difficult), is actually that of tragedy and not of comedy. To criticize the latter, this work will rely primarily on Plato's Cratylus: The Comedy of Language (Ewegen, 2014), which explores this interpretative possibility in Cratylus. This text is a reference for the criticism of versions across Latin America on the role of humor in recent works such as those by Professor Buarque (2011) and more generally by Gregorio Lury et al. (2018) in Ibero-America. The argument will be aimed to show how this way of interpretation is not viable as it has multiple flaws, given that the Platonic discourse ultimately leads to building the polis in such a way that comedy cannot.

Gadamerian hermeneutics was used as our work methodology since its aim is for the text to be entirely understood rather than just isolated sections. Reference to words such as laughter and tragedy are central to the works by Plato and his commentators. To this end, the work is based on Plato's work, making references in their original language to Plato and his commentators' works. As matter of course, we have relied on translations for syntax purposes. A beautiful contribution to the relevance and decisive role of writing in the spiritual formation was made by Jean Brun (1975). In this regard, but in a different vein, in terms of techniques and developments of the implications on how to think about writing, the work of Erick Havelock (1994) has pointed out a rather fortunate path. A further non-sophist chapter in Spanish emphasizing on two great classics of Philosophy, Plato and Aristotle, was presented by Emilio Lledó (1984, 1994, 1999, 2000), who performed a series of exercises around this relationship in Ancient Greece. In this respect, Lledó's work is largely indebted to Georg Gadamer's work which was later consolidated in the Gesammelte Werke compilation, especially on volumes II (1985) and III (1991), about Classical and Pre-Classical Philosophy. 
This work is precisely in the line of thought where the written word, a well-thought-out indication of expression, becomes a significant reference for Platonic interpretation.

To get the point ${ }^{3}$, the dichotomy between tragedy and comedy when classifying the genre of Plato's writing is not strictly speaking the only form of reading possible. Gerald A. Press, author of "Plato: A Guide for the Perplexed", suggests other ways of working with texts: "think of the three readings, briefly, as logical, literary and integrative. Each reading is distinct from the others and their sequence is important. It is also reasonable to think about them as three aspects of the dialogues that you can pursue during one and the same reading." (Press, G. A., 2010, p. 186). Thus, the work of Plato cannot be read in only one direction, that is, merely literary reading at the expense of others in our case and consequently we must undertake a search with more than an idea of systematic philosophy (For a short review of the system concept, it is worth mentioning the remark made by Cassirer about this idea):

If we compare the answers of the eighteen century to these questions with the answers prevailing at the time when that century began its intellectual labors, we arrive at a negative distinction. The seventeenth century had seen the real task of philosophy in the construction of the philosophical "system." Truly "philosophical" knowledge had seemed attainable only when thought, starting from a highest being and from a highest, intuitively grasped certainty, succeeded in spreading the light of this certainty over all derived being and all derived knowledge. This was done by the method of proof and rigorous inference, which added other propositions to the first original certainty and in this way pieced out and linked together the whole chain of possible knowledge. (1932, 6)

[Vergleicht man die Antwort, die das achtzehnte Jahrhundert auf diese Fragen gegeben hat, mit den Antworten, die es zu Beginn seiner intellektuellen Arbeit vorfindet, so fällt zunächst eine negative Entscheidung auf. Das siebzehnte Jahrhundert hatte die

\footnotetext{
${ }^{3}$ An approximation to this problem has been already discussed in the article "Dialogue and Comedy in the work of Plato: An approach to the genre issue", published in the Dissertaciones journal on January 5, 2016.
} 
eigentliche Aufgabe der philosophischen Erkenntnis im Aufbau des philosophischen „Systems“ gesehen. Wahrhaft „philosophisches“ Wissen erschien ihm erst dann erreicht und erst dann gesichert, wenn es dem Gedanken gelingt, von einem höchsten Sein und einer höchsten, intuitiverfaßten Grundgewißheit ausgehend, das Licht dieser Gewißheit über alles abgeleitete Sein und über alles abgeleitete Wissen zu verbreiten. Dies geschieht, indem durch die Methode des Beweises und der strengen Schlußfolgerung an die erste ursprüngliche Gewißheit andere Sätze mittelbar angeknüpft und auf dem Wege dieser mittelbaren Verknüpfung schließlich die gesamte Kette des Wißbaren durchlaufen und in sich geschlossen wird.]

at hand, the idea of a vision as proposed in Platonic terms with the name of theory (The same reference to Plato's vision was addressed by the author himself, Gerard A. Press, in chapter 11 of the text cited above. Making reference to Plato's philosophy as a vision rather than as the system that provides all answers is more in line with the form of writing adopted by the Greek himself. Such vision promoted by the author would help to understand why more than a theory of knowledge, an ethical conception or perhaps an aesthetic theory, the author actually promotes in sum an educational and transformational stance that will begin, as we will see, from the very fact that there is a link between the word and the idea, rather than between the word and the particular object).

Ewegen (2014) in his Plato's Cratylus: The Comedy of Language reflects on the link between this Platonic writing style and a genre other than tragedy, namely comedy ${ }^{4}$ To that extent, the interpretation, by assigning a certain genre to the Platonic elaboration, will alter the meaning of words in general, which would be precisely interpreted according to the genre intended to

\footnotetext{
${ }^{4}$ This connection does not seem to be a proper thought by Ewegen (2014) but similarly supported by Gerald A. Press (2010), who indicated that not only the Cratylus Dialogue, but Plato's entire work can be read in the form of comedy. "Overall, though, the dialogues may owe more to the comedies than to the tragedies on account of their extensive use of humor, irony, playfulness and staged effects." This discussion will move in another direction by arguing that there is an educational interest not only for Cratylus elaboration but, by extension, for Plato's work in general (not discussed here) and that Plato's work, while difficult to identify a genre, contains more tragedy than comedy elements. These elements stand out inasmuch as it is a more formative or educational proposal than a merely critical social practice, which is more identified with the dart of humor. Further discussion on this matter will be done at a later stage.
} 
be linked to. In the same vein, the understanding of each of Plato's terms in this Dialogue can also change. To start, some brief notes will be made on how Ewegen includes Plato's reflection on the Cratylus to show the relationship that, in my opinion, is more related to the tragic genre in the Dialogues writing than to comedy genre. An attempt to establish the same relationship will be done with Press' work by finding arguments that will make Ewegen's position a little more precise. All this aims to link the genre to Plato's reflection by using elements inherited from tragedy rather than from comedy, as the latter seems to have been pointed out by the author, and moreover, to essentially link the writing genre with a decisive genre in the construction of citizenship.

For understanding Plato's work as an exercise linked to comedy, Ewegen presents different guidelines. Firstly, he makes extensive use of the genre, not precisely applied to the brief remarks based on Aristotle's Poetics (cfr. 1449 a y ss) in which there is a strong association between tragedy and comedy. However, despite not exploring the few guidelines in Aristotle, our author makes an interpretation of the meaning of laughter for Plato based on the famous story of Thales as told in the Theaetetus. Plato affirms that Thales in the Theaetetus (174 a-b) that ... Why, take the case of Thales, Theodorus. While he was studying the stars and looking upwards, he fell into a pit, and a neat, witty Thracian servant girl jeered at him, they say, because he was so eager to know the things in the sky that he could not see what was there before him at his very feet. The same jest applies to all who pass their lives in philosophy. ${ }^{5}$

The story discussed by Ewegen supports the claim that laughter is worth paying attention to. However, the story of Thales told by Plato in the Theaetetus, which does not have just this interpretation but also, in fact, the more serious side of the story told by Plato which has been attributed to Thales to show in general what philosophy would be, is also illustrated by Heidegger when he indicates, with limited nuances, that also in the question about philosophy (about the thing) "(...) and genuine housemaids must have something to laugh about."

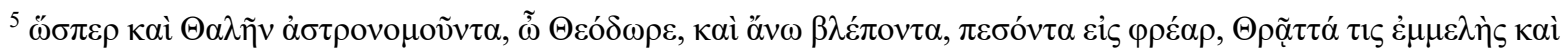

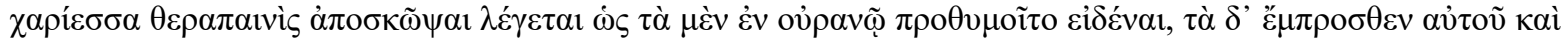

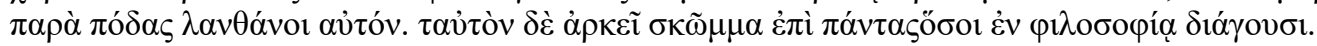


(Heidegger, 1984; 3$)^{6}$. In contrast, and without any appeal to what or who says it is actually a housemaid and thereby unable to understand what Thales does, let alone with the strong social barrier of her time, Gadamer points out something different when telling the history of philosophy stating that:

It is said that [the fact that Thales is supposed to have fallen into a well] but it was not. Thales did not fall into a well, but he climbed into a dry well as if it were like the telescope of the time. Thanks to the walls of the well, he could get a more precise means of stargazing. Thanks to that technique, he was able to exactly record them to create the first telescope ${ }^{7}$.

Thus, the interpretation of the story of Thales has many roots. Thus, such identification with a single interpretation must be carefully considered even more so when the sole interpretation of a section from the Theaetetus is related to the comedy genre, as well as the humor contained in its etymologies, as pointed out by Ewegen. The selection or approach to the comedy genre would be difficult to legitimize in accordance with the eminently educational purpose that, unlike comedy, tragedy pursues and, therefore, in a similar vein to this genre, the Dialogues. It is worth remembering that Aristotle stated on the subject of the comedy genre (1449 a $30 \mathrm{y}$ ss) that: "Comedy is, as we have said, an imitation of characters of a lower type (...)." Such imitation could thus only be, as in the case of imitation in education, a model for mockery rather than a model for learning, which is evident in the increase in shortcomings. Just the opposite is the case of the introduction of the Platonic hero par excellence: Socrates, who is imitated in his actions.

To this end, Plato uses a part of the story on Thales in the Theaetetus about the origin of philosophy is to recover the conception of laughter created there (cf. Theaetetus; $174 \mathrm{~b} \mathrm{10}$ ). Moreover, in order to establish a conceptual framework, Ewegen makes use of some other elements such as those pointed out by Leo Strauss in The City and Man and John Sallis in

\footnotetext{
${ }^{6}$ Und was eine rechte Dienstmag ist, muss doch auch etwas zum Lachen haben.

${ }^{7}$ The above statements can be found at https://www.youtube.com/watch?v=HNf8vhDTnQo (uploaded on July 4, 2015)

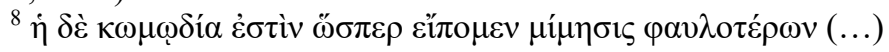


Being and Logos (Cf. Ibid pp. 9-10) about reading the Cratylus. As for the former, Ewegen states that “ (...) In The City and Man, Strauss observes a certain way in which Plato's texts in general tend toward "the ridiculous or, as we are in the habit of saying, the comical" (ibid). Along the same lines, the form in which comical is defined is not exactly the form how Plato would point out it. In contrast, the term comical is used by extension as it is not used in a reasonable way or trying to give an exact idea of what Plato would understand as such, but making use of the term by reference to other inquiries at risk, as later discussed, of quoting the author out of context.

Such identification is, as later discussed, typical of the linguistic turn philosophies. However, despite how persuasive it may be seen from other perspectives of analysis that do not take as a basis any of the Plato's works, which do not assume their meaning within the author's work but instead are part of what traditionally is known as linguistic turn ${ }^{9}$, as they interpret it in an inappropriate manner when it comes to clearly addressing what Plato has pointed out at the time of writing. It is worth remembering that, unlike what happens in the Theaetetus, a dismissive sense of laughter is evident in other sections such as that found in Republic (518 a-b) where Plato states that:

I said, "would remember that there are two distinct disturbances of the eyes arising from two causes, according as the shift is from light to darkness or from darkness to light, and, believing that the same thing happens to the soul too, whenever he saw a soul perturbed and unable to discern something, he would not laugh unthinkingly, but would observe whether coming from a brighter life its vision was obscured by the unfamiliar darkness, or whether the passage from the deeper dark of ignorance into a more luminous world and the greater brightness had

\footnotetext{
${ }^{9}$ When talking about the term linguistic turn we undoubtedly refer to the work of Richard Rorty (1992) The Linguistic Turn: Essays in Philosophy Method (a Spanish version of this text was published by Paidós. The current version was published in 1990). Although it is true that the term linguistic turn, even in its Anglo-Saxon form, include the definite article 'the, the fact is that there is not a single linguistic turn as such so that there are two types of linguistic turns. The first one states that the linguistic sign is plurisignificant, which gives plurality of meanings, widely used in literature. The second one, from which the philosophy of language comes, is related to that extremely rigorous relationship about the precision of the concept, not just about the word, which is recovered by the analytical philosophy of language.
} 
dazzled its vision. And so he would deem the one happy in its experience and way of life and pity the other, and if it pleased him to laugh at it, his laughter would be less laughable than that at the expense of the soul that had come down from the light above. ${ }^{10}$

Thus, the consideration of laughter in Plato is closely related to ignorance rather than knowledge. The act of laughing $(\gamma \varepsilon \lambda \tilde{\alpha} v)$ can be considered as a turning point towards authentic knowledge of things that could not be equally appreciated but now acquire a new value through laughter. However, although this moment of knowledge triggered by laughter is significant, it is not precisely what Plato considers valuable in contrast to the so-called knowledge, something that he bases on the image of light and manifests itself as clarity.

The metaphor of laughter is not only used here. It would be necessary to find direct criticism of those who prepared the comedies included in the Phaedo (70 b-c), in which Plato states that: "Well," said Socrates [as for the argument of the existence of the soul by referring to opponents], "I do not believe anyone who heard us now, even if he were a comic poet, would say that I am chattering and talking about things which do not concern me."11

In this direction, the clarifying line between commas "even if he were a comic poet" leads to the idea that, unlike the objective of the behavioral thread of reasoning and coherence, is elusive to comedy. This is how it is possible to understand that, by linking Plato's reasoning to the genre of comedy instead of tragedy, we would actually have to accept the possibility of the absurd and hence, the possibility of contradiction.

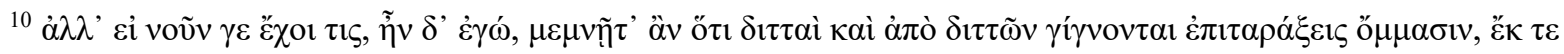

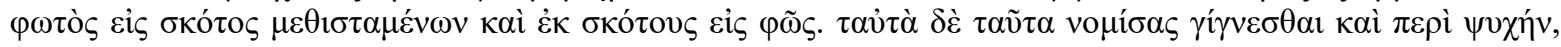

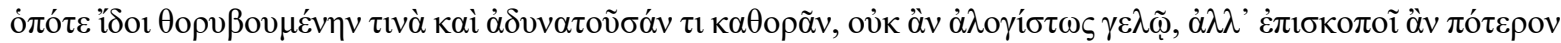

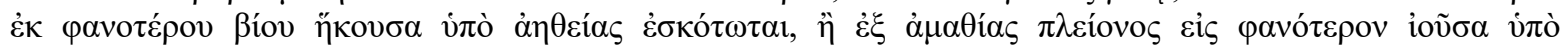

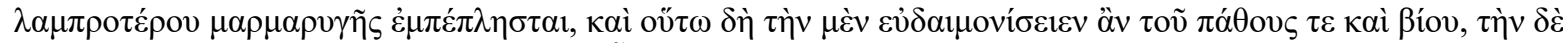

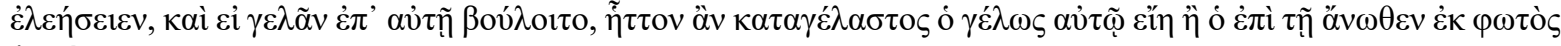

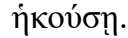

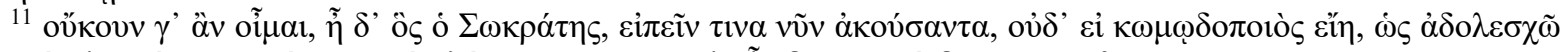

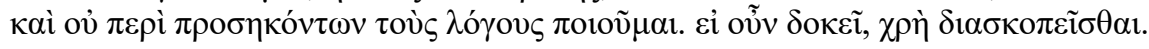


In relation to their chronology, the Dialogues, Phaedo and Republic are precedent to Cratylus ${ }^{12}$ and would be, in our opinion, much more relevant when reviewing the writing proposed in that Dialogue, as opposed to the Theaetetus. This is based on the assumption that there should be some points in Plato's reading that are differentiated but preserved in the unit of the work.

The refence to John Sallis seems to be the source for such humorous interpretation. In his article on Cratylus (cfr. 2006;39), Professor Jairo Escobar Moncada also cites Sallis. When quoting him, Professor Moncada refers to the falsehood of many of the etymologies that Sallis used, but he unintentionally puts this general judgement on Plato's work, including those etymologies that arise from the different constructions based on the Greek language which are not actually jests. It is worth pointing out that not all etymologies mentioned by Plato are false, which would require to examine the text in much more detail to find out the reasons why the author would propose a different type of linguistic constructions than the conventional ones used in Greek. Among these reasons, it is assumed that Plato does turn terms such as soul, purification, etc., although he also preserves the tradition of using these words in their archaic form as in the case of the term nature.

\section{Word Usage}

For the sake of clarity, it is important to be more explicit about the use of these terms. The terms purification and soul contain an explicit reference to existing religious beliefs prior to the fifth century BC and in Plato's century as well. Erwin Rohde makes this point when indicating the association between the meaning of the word 'purification' and the ritual described in different sections of tragedy works:

\footnotetext{
12 To make use of the chronology in the Dialogues, here is the Guthrie classification (cfr.2000;50):Early Dialogues: Apology. Crito, Charmides, Laches, Lysis, Euthyphro, Hippias minor and major, Protagoras, Gorgias, Ion.Middle Dialogues: Meno, Phaedo; Republic, Symposium, Phaedrus. Euthydemus, Menexenus, Cratylus.(Early Dialogues: Crito, Laches, Lysis, Euthyphro, Hippias minor and major, Protagoras, Gorgias, Ion).
} 
Purification from the blood of the slam was necessary even in the case of the unpunished agent of what the state regarded as justifiable homicide, it restored the man hitherto regarded as "unclean, to participation in the religious gatherings of state and family which could not have been approached by an unpurified person without suffering defilement. The Homeric poems know nothing of any such religious purification of those who have incurred the stain of blood. $(1903 ; 271)^{13}$

The term 'purification' evolves from the religious rituals observed in its use in tragedy to its use in Plato's philosophy. Its use in relation to the state resulting from the escape from ignorance and knowledge and truth, which does not precisely obey the indexical plane, leads to a different use of the word. Now observe the following citation in Cratylus (396 e - $397 \mathrm{a}$ ): .... we ought today to make use of this wisdom and finish the investigation of names, but tomorrow, if the rest of you agree, we will conjure it away and purify ourselves, when we have found someone, whether priest or sophist. ${ }^{14}$

Plato's words call for a double use of the word purification, whether it is given by a priest in the ancient Greek way or by a sophist corresponding to the new model of Greek education that Plato institutionally established. Thus, purification will be properly granted for its capacity to take one out of a state and lead to another, provided that permission is given for this journey, which is done in Republic Book VII, to take us out of shadows where everything seems the same to the light where nuances and clarity are plentiful.

Regarding the term soul, there is a rather interesting phrase used by Rohde. In Platonic philosophy, soul is deprived of corporeality and life force to essentially become a force having a different character than physical force one, and thus, to contain within itself the thing that

\footnotetext{
${ }^{13}$ Die Reinigung vom Blute des Erschlagenen, deren auch der sonst straflose Thäter einer gesetzlich erlaubten Tödtung bedarf, giebt den bis dahin als ,unrein' Betrachteten der sacralen Gemeinschaft in Staat imd Familie zurück, der ein Unreiner nicht nahen kann, ohne auch sie zu beflecken. Die homerischen Gedichte wissen von einer solchen religiösen Reinigung Blutbefleckter nichts

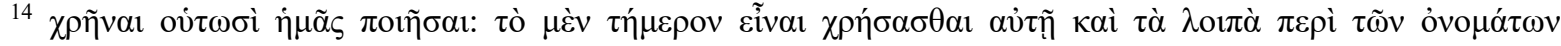

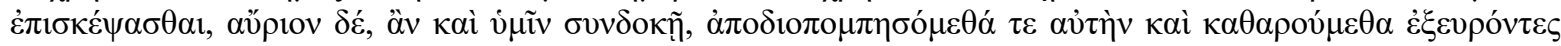

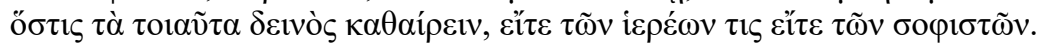


animates the body, giving it the capacity to be intelligible. Rohde points out the following on this subject:

But how are to think of this "Psyche" that, unnoticed during the lifetime of the body, and only observable when it is "separated" from the body, now glides off to join the multitude of its kind assembled in the murky regions of the "Invisible" (Aides)? Its name, like the names given to the "soul" in many languages, marks it off as something airy and breathlike, revealing its presence in the breathing of the living man. It escapes out of the mouth - or out the gaping wound of the dying - and now freed from its prison becomes, as the name well expresses it, an "image" (eidolon) $(1902,3)^{15}$

Similarly, the word 'soul' can be linked to Homeric poems and even during the time of tragedy, as Rohde seems to do, to physical elements. A different fate will occur with the connotations of the word when reaching the fifth century through Orphic cults in which the word becomes a spiritual entity and then will have bear the weight of the different stains it shows. Those stains ( $\dot{\alpha} \mu \alpha \rho \tau i ́ \alpha)$ will be purified, either by successive reincarnations or initiation into the mysteries. Plato considers the word soul as something different. regarding this, the following can be observed in Cratylus $400 \mathrm{c}$ : ... But I think it most likely that the Orphic poets gave this name, with the idea that the soul is undergoing punishment for something; they think it has the body as an enclosure to keep it safe, like a prison, and this is, as the name itself denotes, the safe $(\sigma \tilde{\omega} \mu \alpha)$ for the soul, until the penalty is paid, and not even a letter needs to be changed. ${ }^{16}$

\footnotetext{
${ }^{15}$ Aber wie hat man sich diese „Psyche" zu denken, die, bei Leibesleben unbemerkt geblieben, nun erst, wenn sie „gelöst" ist, kenntlich geworden, zu unzähligen ihresgleichen versammelt im dumpfigen Eeiche des „Unsichtbaren" (Aides) schwebt? Ihr Name bezeichnet sie, wie in den Sprachen vieler anderer Völker die Benennungen der „Seele", als ein Luftartiges, Hauchartiges, im Athem des Lebenden sich Kundgebendes. Sie entweicht aus dem Munde, auch wohl aus der klaifenden Wunde des Sterbenden - und nun wird sie, frei geworden, auch wohl genannt „Abbild" ( $\varepsilon i \delta \omega \lambda$ ov)

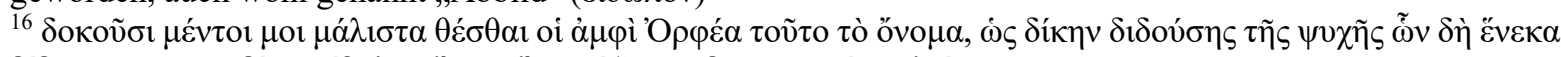

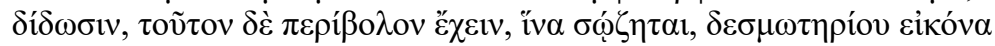


This indication on the definition of the word 'soul' given by Plato, unlike our understanding of the word 'body', gives us an idea of its actual meaning. From this perspective, Plato, in Dialogues such as Republic, may think of a tripartite soul and give the intellectual part the purest form, its noetic capacity, as the domain of the sensible world (cfr. 436 a).

\section{Back to Theaetetus}

Now, it is time to leave Plato's considerations about his new language, his new use for words and, therefore, his etymological constructions, and retake Ewegen and his conception of Cratylus as comedy based on the reference to Thales in the Theaetetus. However, reading the laughter and the lack of good education Dialogue from a different perspective, the behavioral threat of Plato's discourse will show certain limitations about laughter. Note that after Ewegen's quote on the formulation of Thales' story, there is a close relationship between laughter and the lack of education (cfr. Theaetetus $75 \mathrm{~d}-\mathrm{e}$ ) since it is mentioned in both Theaetetus and Republic as referenced above in relation to the lack of understanding in a specific situation. Thus, this interpretation of laughter in Plato, at least in the middle dialogues on which Cratylus focuses, is based on an absence of clear knowledge; the relationship between this Dialogue and comedy would have certain lack of accuracy not only because of Ewegen's retrospective interpretation but also because of the fact that Plato's allusion to laughter in Theaetetus is taken out of context and, thus, a resulting absence of confrontation with other sections of his work. Hence, our author fails to provide context for extracting the laughter factor and, in turn, he engages in an excessively convenient interpretation, in accordance with his purpose; finally, with this procedure, Ewegen incurs, in addition to everything else mentioned above, a suppression of the information offered in the text by avoiding confrontation, as in the case of the previous quotations, with other references not only to laughter but also to comedy writers to give a much more complete idea of the relationship between the Cratylus Dialogue and comedy.

The existence of the suppression of information can also be pointed our when Ewegen tries to legitimize his inquiry about Plato and comedy again. To give an example of this, on page 99 
of Plato's Cratylus: The Comedy of Language, Ewegen indicates that the use of the verbs $\sigma \kappa \omega ́ \pi \tau \omega$ (to inquire) and $\sigma \kappa о \pi \varepsilon ́ \omega$ (to joke) would give a great indication of the comical character of his inquiry by making small changes in words moving from the philosophical deduction mechanism to literary conjecture. A further example is given when the same author seeks to relate the word $\alpha \sigma \tau \tau-\not \alpha v \alpha \xi$ (Lord of Impotence) to the word 'impotence' on page 103.

However, we must first make a brief detour in order to better understand what precisely is at work behind Socrates' example. Though Socrates has interpreted 'A $\sigma \tau \check{v} \alpha v \alpha \xi$ as meaning "lord of the city," the name can also be interpreted another way, a playful way, one which sheds light upon our interpretation of the dialogue so far. The name 'A $\sigma \tau \breve{v} \alpha v \alpha \xi$ could be analyzed as

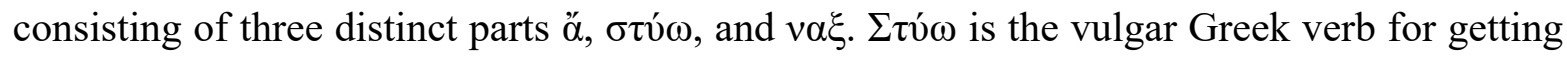
an erection, used occasionally by Aristophanes. Preceded by tha alpha-privative ó $\sigma \tau u ́ \omega$ means

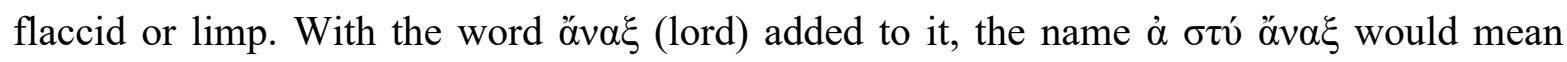
something like "Lord of impotence".

For this purpose, Ewegen must not only take the word out of context, but also interpret it according to his will, making a terrible use of Greek morphology, strictly following Hermogenes' instructions of a private language, a privative alpha together with a verbal lexeme, a construction that, as we can see, has no place in Plato's work since the word refers directly to the use of a noun and not precisely to a verb. In the context where the word is extracted its meaning is divided in the lord, $\alpha ّ v \alpha \xi$, of the walls, $\alpha \sigma \tau v$. These other two linguistic evidences serve then to point out how this mechanism of analysis alters the purpose of Plato's text, which is not even to make an inquiry into language but, from that part of language, the

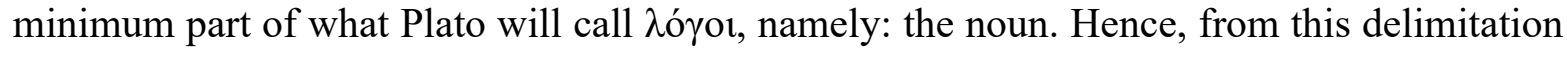
of the problem, and from highlighting the elements that make up the name, appears its play with words and its precision in some consonants as later discussed; hence also the importance of this research of the relationship between the composition of the name and the ordering that must be done of each of its letters. 


\section{Conclusion}

These difficulties in the interpretation of Ewegen, and therefore those that have been used in the Latin American context, allow us to argue the following. More than comedy, the discursive genre with which not only Cratylus but also Plato's work should be read, if it is to be linked to a particular genre (which is doubtful enough thanks to the same testimony already given by Aristotle) is that of tragedy. It should be clarified that despite being called Dialogues, the Platonic exercise is revealed to us in the form of a writing, a writing that tends to reflect on the exactness of what we call each thing. This exercise then possesses, according to what we have defended here, a referential framework which tends, above all, towards a new model of education for the Greek people, this exercise which, as we noted before and which is one of the differential aspects with the interpretation of Ewegen, enjoys a formal framework that is sufficiently alien to those who configure laughter.

\section{References}

Buarque, L. (2011) As armas cômicas, os interlocutores de Platão no Cratílo. Ed. Hexis.

Cassirer, E. (1932) Die Philosophie der Aufklärung. Ed. Verlag

Chantraine (1968) Dictionnaire étiologique de la langue grecque. Ed. Klincksiek

Cratílo, Fedon, República. Teteto:

http://www.perseus.tufts.edu/hopper/text?doc=Perseus\%3Atext\%3A1999.01.0172\%3Atext \%3DCrat.\%3Asection\%3D436e (date of Access: June 19, 2020)

Escobar, J. (2006) ¿Cómo se puede llegar tarde al conocimiento de las cosas? Sobre logos y ousia en el Cratílo de Platón. En: Estudios de Filosofía. Instituto de filosofía Universidad de Antioquia. Agosto del 2006 p. 29 ss

Volumen 2. Número 1. Enero - Junio 2022

ISSN: 2745-0333 (En línea) 
Ewegen M. (2014) Plato’s Cratylus, The comedy of Language: Ed. Indiana Univerity Press.

Gadamer, H, G. (1991) Gesamte Werke, Griechische Philosophie. Plato im Dialog Ed. J. C. B Mohr. Tubingen

Gadamer, H, G. (1985) Gesammelte Werke. Griechische Philosophie. T. II . Ed. J.C.B Mohr.

Gadamer, H, G. (1990) Hermeneutik. Wahrheit und Methoden. Ed. J.C.B Mohr.

Gerald, P. (2010) Plato a guide for the perplexed. Ed. Continuum.

Heidegger M. (1984). Die Frage nach dem Ding. Ed. Vittorio Klostermann

Havelock E. (1994) Preface to Plato. Harvard University Press.

Lledó Iñigo, E. (1984) La memoria del logos. Estudios sobre el diálogo platónico. Ed. Taurus.

Lledó Iñigo, E. (2000) El surco del tiempo. Meditaciones sobre el mito platónico de la escritura y la memoria Ed. Crítica.

Lledó Iñigo, E. (1998) El silencio de la escritura. Ed. Espasa Calpe.

López Rivera J. (2016) “Diálogo y comedia en la obra de Platón. Un acercamiento al problema del género" Publicado en la revista Dissertaciones el 5 de Enero.

Rode, E. (1903) Psique. Seelencult und Unsterblickeitgsglaube der Griecehen. Ed. J.C.B Mohr.

Richar R. (1992) The Linguistic turn: recent essays in philosophy method: Ed. University of Chicago 